\title{
The Usefulness of the Discrete Choice Experiment in Providing Effective Healthcare
}

UDK: $614.2(045)$

\author{
Nikolina Dukić \\ University of Rijeka, Faculty of Economics \\ ndukic@efri.hr
}

\begin{abstract}
Given that in times of crisis the burden of chronic disease is increasing, preventive interventions are becoming more important as they affect the maintenance and improvement of the population's health, therefore reducing government spending on the sick leave and disability benefits. As public healthcare is characterized by administrative decision-making and relying on non-market mechanisms in the resource allocation, it requires the implementation of economic evaluations. This discussion shows that because the specifics of public healthcare complicate the data collection of revealed (market) preferences, it is necessary to rely on stated preferences of respondents in order to evaluate the economic value of health interventions as well to improve public health care interventions and make them more patients oriented. Also, this article explores the method of discrete choice experiment along with its applications in healthcare, which seeks to identify the marginal rate of substitution between relevant attributes of public healthcare intervention and its impact on the patients' choice, hence enabling a broad application of the method.
\end{abstract}

Keywords: public healthcare, health spending, prevention, stated preferences, discrete choice experiment

JEL: D61, D78, $H 51,111,118$

\section{Introduction}

Public funding of healthcare implies administrative decision-making and relying on non-market mechanisms in the resource allocation, which requires the formation of high-quality public health policies. But many health systems are characterized by the increased health spending and a kind of healthcare crisis, which is not caused solely due to lack of money (Pelletier et al., 2009), but also due to the non-compliance of healthcare spending, the fragmentation of healthcare services, the non-existence of continuous healthcare and the 
inadequate funding of the cost-effective preventive interventions. Achieving efficiency in the use of public healthcare resources is not an easy task and involves harmonization at the macro and the micro level. At the level of preventive health interventions the efficiency can not be achieved without a satisfactory level of effectiveness, in achieving which the demand side factors (patients) play a significant role.

The response rate of the target population influences the effectiveness of preventive health interventions, but it also presents the information on revealed preferences of the target population. Furthermore, under the assumption of the rational behavior of individuals, the response rate to preventive interventions should be high whilst the low response rate of the target population (revealed preferences) would imply small social value of preventive health interventions. However, the question arises whether revealed preferences (response rate), in the case of (non-)response to preventive interventions, provide insights into the value (utility) of preventive interventions. Namely, it is well known that even though individuals might consider a certain action to be beneficial they will not necessarily act in accordance with it, which can lead to a distorted value based on revealed preferences. Therefore, the hypothesis of this paper is: by studying individuals' stated preferences it is possible to improve preventive public health interventions and determine their economic value by using method of discrete choice experiment (DCE). The purpose of this paper is to highlight the economic importance of the early detection and prevention of chronic diseases and the role of patients' preferences in creation of optimal health service.

Accordingly, the second part of the paper deals with the economics of prevention and the determinants of individual and social demand for preventive healthcare. After this, the third part of the paper reflects the evaluation of benefits in healthcare with an emphasis on the importance of valuation of stated preferences when conducting economic evaluation or improving healthcare interventions. Finally, one of the most promising methods of stated preferences in healthcare, a method of discrete choice experiment, is presented in the fourth part of the paper in which the theoretical and methodological framework is given along with the review of its application in healthcare.

\section{Economics of preventive healthcare}

The traditional approach to healthcare is based on the concept of the disease with an uncertain appearance (and outcome), and limited duration of a medical intervention. However, the typical patient has changed and it has become common to suffer from several diseases at the same time (Kenneth \& David, 2006; Nolte et al., 2008) and to still experience extended life expectancy. Also, it is anticipated (Mathers \& Loncar, 2006) that by the 2030 the chronic 
diseases will make $70 \%$ of the global burden of disease ${ }^{1}$ and cause $80 \%$ of deaths worldwide.

Poor health and chronic illness can affect the economy through spending and savings (capital formation), as well as the level of education (Suhrcke et al., 2006). Reduced household consumption and the level of education, due to illness, have a negative impact on gross domestic product, while at the same time expenditures for chronic diseases across Europe are taking an increasingly large share in the government and private consumption. Empirical research at the micro level shows that chronic diseases reduce wages, earnings, labor force participation and productivity while, also, affecting early retirement, disability benefits and high rate of employee turnover (Suhrcke et al., 2006). Therefore, it is necessary to redesign the public health system towards a model of integrated care ${ }^{2}$ with a focus on chronic disease management ${ }^{3}$ and to ensure greater sensitivity to patients' needs and preferences, consequently increasing the efficiency of the provision of public healthcare.

The prevention of chronic diseases that reduces morbidity and disability has a significant part in integrated medicine and there is a growing interest towards the prevention (Clarke, 2010). Given that in times of crisis the burden of chronic disease is increasing, preventive interventions are becoming more important as they affect the maintenance and improvement of the population's health, therefore reducing government spending on sick leave and disability benefits. Also, the effective use of the prevention helps to reduce the need for curative care and the associated high costs of medical treatment (Wei-Hua et al., 2010; Sassi \& Hurst, 2008) which is of great importance nowadays. However, investment in prevention is not only in the interest of the government but also in the interest of the employers (Pelletier et al., 2009), who can save 2-3 dollars on average, in costs associated with the loss of productivity due to employee illness only by spending a dollar on medical/pharmaceutical costs.

\subsection{Individual demand for prevention}

Empirical studies of demand for healthcare are theoretically based on Grossman's (1999) model of human capital in which individuals invest in their health and the level of individual's health directly affects the level of his utility, but also the time available for market and non-market household production ${ }^{4}$. In other words, the utility of consumption which an individual derives from

1 The WHO project »The Global Burden of Disease" estimates incidence, prevalence, severity and duration, and mortality for more than 130 major causes of illness, and includes data from 2000 onwards for the members of WHO and various sub-regions around the world.

2 According to the model of integrated care treatment is organized in a way that the healthcare is better connected among the full range of health services. Examples from Europe are the introduction of case management by the NHS in the UK, and the Spanish pilot project in which the entire medical care is available from a single source (Busse et al., 2010).

3 In a number of European countries there are considerable variations in the approaches to chronic disease management that are being implemented in different healthcare settings (McKee \& Nolte, 2004).

4 Households combine market goods and their time in order to produce the goods that are the ultimate source of their utility (Becker, 1965). 
his income depends directly on his health state. If spending on medical care $(M)$ decreases, the stock of individual's health $(H)$ will also decrease $H(M)$, influencing the level of income $Y(M)$ to decrease. Consequently, the amount of resources available for spending on other goods will increase at a decreasing rate up to a certain point after which every further reduction in medical care costs would reduce the health state of the individual. This will cause the reduction in income that will overturn savings in medical costs, leading to further reduction in the overall level of consumption. Finally, when medical care $M=0$, the income $Y=0$ at the level of consumption $X=0$.

The compromise between different goals of consumption and health can be shown by a conventional microeconomic optimization model, keeping in mind that the marginal benefit of investing in additional unit of health contains the consumption as well as the investment component (Zweifel et al., 2009). The first relates to the direct increase in utility due to reduction of time spent in illness and the other relates to indirect increase in utility through the possibility of increasing weatth and income. Consequently, the demand for medical care is derived from the demand for health and by investing in prevention an individual can increase his utility while at the same time reducing it by sustaining from unhealthy activities and consumption. From an economic perspective improvement in health is not the only purpose of human life and individuals derive utility from various forms of consumption and activities, of which only a small portion ensures a good health.

The insurance model, which determines the impact of health insurance coverage on the individual's demand for prevention, is also used in explaining the demand for prevention. Namely, if a patient is experiencing prevention and curative care as substitutes (Phelps, 1978; Meier, 2000), a decrease in the price of curative care will decrease the demand for prevention, potentially leading to problem of ex ante moral hazard. But, according to the empirical research (Kenkel, 2000), pronounced reduction of prevention among the insured individuals was not found. The reason may be that, according to the model of human capital, health is the ultimate form of utility as well as the "means" for enabling other form of utility and good health is a function of both curative and preventive care. Also, empirical results suggest that curative care may actually complement the use of prevention as in the case of early detection of breast and cervical cancer (Kenkel, 1994), meaning that individuals with covered curative costs find the early detection very useful.

\subsection{Prevention and social welfare}

In principle, prevention has greater potential than treatment of chronic disease for increasing the social welfare by decreasing or avoiding the burden of chronic disease. However, there are at least two significant differences between prevention and curative care (Sassi \& Hurst, 2008) that should be taken into account when considering social welfare and the demand for prevention. Firstly, the goal of prevention is to change the conditions 
giving rise to the occurrence of disease, including the environment in which people live, the level of education and their way of life. Modification of these terms includes certain sacrifices by individuals at an additional cost of material resources. Secondly, healthy individuals are the target population of preventive interventions, therefore the benefits of reducing the risk of developing the disease is seen in the future, which is reducing the value of prevention in the present. Thus, the extent to which prevention can improve the social welfare is defined by mutual relationship of previously mentioned sacrifices and the present value of future risk reduction.

When considering the social benefits of prevention it is important to distinguish between two basic categories of prevention (Kenkel, 2000). The first relates to primary prevention, such as vaccination or healthy lifestyle which reduces the likelihood of disease occurrence, while the secondary prevention includes activities such as screening tests which minimize the consequences of disease and limits the loss of health (Kenkel, 1994), without affecting the probability of disease occurrence. The introduction of public preventive health interventions often requires proof of substantial cost savings and according to Russell (1986), very simplified, it depends whether the cost of prevention will be less than the cost of treatment multiplied by the incidence rate ${ }^{5}$ without the prevention. This formulation does not make much sense in calculating the cost-effectiveness of secondary prevention (early detection) because it does not affect the incidence rate but increases the success of treatment and reduces future medical costs.

Given the growing prevalence of chronic disease, secondary prevention can achieve significant savings. Therefore, the goal of secondary prevention is to detect as many diseases at their early stage when the likelihood of curing is greater and the cost of illness is lower. Thus, the success of preventive public health intervention is determined by the response rate of target population. Keeping that in mind, the next chapter will review the importance of stated preferences in public health decision-making.

\section{Evaluation of benefits and stated preferences methods}

Scientific advances in medicine and technology have contributed to the increase in quality of healthcare, which is on the other side limited by the availability of resources in the form of time, people, money, which creates a gap between the technically possible and economically feasible (Poulsen et al., 2008). Economic evaluations in health, which are theoretically based in welfare economics, have shown to be a good decision-making framework in situations of budget constraint and there is an increasing interest in their

5 The incidence rate measures the number of new patients in a defined period of time compared to the total number of persons multiplied with the monitoring time. 
use ${ }^{6}$ as the implementation of economic evaluation plays an important role in prioritizing healthcare costs.

If the government wants to invest its limited resources in public healthcare programs that will be of greatest interest to the community, it is necessary, along with the cost side, to evaluate the benefit side which entails the issue of the definition and measurement of the benefits. In theory, the evaluation of benefits in healthcare will depend on the selection of one of the two dominant approaches which are welfarism and extra-welfarism (McGuire, 2001). According to welfarism, the outcome of healthcare is assessed according to its contribution to the overall level of efficiency compared to the other arguments of the utility function, while extra-welfarism assesses the outcome of healthcare according to its contribution to health solely. For extrawelfarism the only relevant are the changes in health and not the changes in the overall level of utility so the benefits of healthcare are expressed through the impact on mortality along with the health related quality of life for which generic measure of Quality Adjusted Life Years (QALY) has been developed.

\subsection{Orientation towards broader concepts of benefits}

A significant amount of research in the field of healthcare economics is based on a non-monetary evaluation of preferences and the evaluations of benefits, within conducted economic evaluations which are almost entirely based on health outcomes (Birch \& Donaldson, 2003), as evidenced by the widespread use of QALY in the cost-utility analysis (CUA). However, the criticism of the use of QALY followed, arguing that the exclusive focus on the maximization of a single defined objective (health) is neglecting many other important criteria in public health prioritization, such as needs, efficiency and equality (Golan et al., 2011; Green, 2009; Gyrd-Hansen, 2004; Mirelman, 2012). Besides those, another objection to the QALY refers to the neglecting of social preferences for the equitable distribution of health.

If the above mentioned as well as other non-health benefits are considered to be relevant in the assessment of social welfare (which would depend on the selection of welfarist or extra-welfarist approach), it is necessary to take into account the value of non-health and process characteristics (Moony, 1994). This has been confirmed by empirical research (Ryan, 1999) in which patients were willing to trade-off the changes in health outcomes for process features such as waiting time, cost etc. Consequently, the cost-benefit analysis (CBA) that expresses healthcare benefits in terms of individual willingness to pay (WTP) grows in importance as its evaluation criteria is utility maximization (McGuire, 2001).

6 For example, in Australia, Canada, USA, Sweden, Portugal, Finland, UK, Holland, Germany, Ireland (Drummond \& Sculpher, 2006) there is an upward trend in the use of economic evaluation (mainly cost-effectiveness and cost-utility analysis) in public healthcare in order to achieve efficiency. 
According to welfare theory, individuals are the best judges of their wellbeing and if under the assumption that the maximum amount individuals are willing to pay (sacrifice) for a certain good or service indicates their level of utility, monetary value of benefits is determined by individual willingness to pay (WTP). Therefore, the level of well-being can be determined by observing actual choices of individuals in the market (RP) or by testing hypothetical choice of the individuals (SP). Namely, when certain goods or services are traded in the market, buyers and sellers reveal their preferences directly through price and quantity signals, while in the absence of the market mechanism (as in the case of public health) preferences are not revealed in the same manner. Therefore, the economic evaluation is required for the assignment of value to non-market goods or services.

The value of goods and services can be expressed in terms of money (WTP) and in non-monetary units (QALY), using an indirect approach with revealed preferences data or direct approach with stated preferences data (Mclntoch, 2010). By using the indirect approach the value of non-market good or service is revealed by some complementary market (e.g. patients' transportation costs), while direct approach requires the construction of the hypothetical market where respondents are asked to state their preferences for nonmarket good or service. Therefore, within the CBA, the benefits of healthcare can be determined by using SP or RP methods which do not require benefits to be expressed in terms of health and health related quality of life only (QALY).

\subsection{Eliciting stated preferences to inform decision-making}

Economists are typically (justifiably) skeptical when it comes to relying on what consumers say that they will do in relation to what they actually do. However, there are situations when there is no other choice but to rely on the testimony of the consumer/patient, or do nothing, as in the case of healthcare. Louviere, Hensher and Swait (2000) in one of the most cited books in the field of discrete choice argue that, along with the well-developed economic theory as one, there are many reasons why economists should be interested in hypothetical choices (SP) of economic agents. Briefly, the appropriateness of $\mathrm{SP}$ compared to RP is reflected in situations when it is necessary to estimate the demand for a new product with new characteristics and features, when there is very little variation of the explanatory variables on the market ${ }^{7}$, when they are highly collinear, when the data collection on the market is extremely time-consuming and expensive, and when the product is not traded on the market, which is important for public healthcare. In this sense, it is possible to determine the overall economic value (use value, non-use value and option value) with SP (Kjær, 2005).

7 Competitors in numerous industries coordinate prices and levels of service and the price remains unchanged over a longer period of time. 
The interest for using the SP techniques has increased dramatically in the environmental economics and the health economics from the mid-1990s onwards, and can be classified generally (Merino-Castello, 2003) as contingent valuation (CV) and multi-attribute valuation (MVA). Lately, in a number of $\mathrm{SP}$ research in health economics discrete choice experiment (DCE) - a form of MVA is being used which can be attributed to numerous advantages of the methodology. Namely, in DCE respondents make choices in a manner consistent with the way in which they would actually choose in a real market and it is more appropriate in situations when it is necessary to evaluate several attributes simultaneously, while CV would need the construction of more scenarios. Another advantage of DCE in relation to CV is in reduced multicollinearity between the attributes and the avoidance of problems in the respondents' answers that are characteristic for the CV method (Bateman et al., 2002). Also, DCE seeks to identify the relationships in which attributes are substituted by each other, at the same time maintaining the same level of utility, i.e. the marginal rate of substitution (MRS) and its impact on the respondents' choice, hence enabling a broad application of the method. In this sense, the most advantageous and certainly unique to DCE is that it can be used in both CBA (estimating monetary value of WTP) and CUA (estimating the utility weights within QALY) (Ryan et al., 2006; Lanscar et al., 2011).

Finally, the reason for conducting DCE is twofold. Firstly, it leads to the structured conclusions about the respondents' preferences related to the research question and the possible trade-offs between the attributes. Secondly, the researcher can determine the amount to which patients are willing to pay themselves for some of the elements (attributes) or a healthcare service as a whole. Besides that, monetary evaluation (WTP) is a way of quantifying the value of healthcare intervention in the broadest sense.

\section{Discrete choice experiment in healthcare}

The appropriateness of DCE method is based on two basic assumptions. First, the alternatives (goods or services) differ according to their characteristics (attributes) (Lancaster, 1966) and second, the evaluation of the alternatives depends on the attribute levels. By changing the attribute level it is possible to predict the changes in individual's choices between different alternatives and therefore to determine individual preferences. This way it is possible to design an optimal service within the available resources which is very important in ensuring cost-effectiveness of preventive healthcare interventions.

\subsection{Theoretical foundation of the discrete choice experiment}

The theoretical framework of DCE contains elements of traditional microeconomic theory of consumer behavior, such as the formal definition of rational choice. However, the fundamental shift from the traditional consumer theory is reflected in the setting that the consumer obtains utility 
from the characteristics (attributes) associated with the good, and not from the good per se (Lancaster, 1966). This methodology collects data about the respondents' preferences in hypothetical scenarios, while the new scenario is formed with every modification of the level of the attributes. By providing certain variations in the scenarios, it is possible to determine the relations in which the attributes are substituted by each other, and to examine the extent to which each of the attributes affects the choices of the individuals. The scenarios with the alternatives and product descriptions are commonly performed with the technique of experimental design in order to encourage respondents to trade-off, in this way taking into account the concept of opportunity cost in the process of preference elicitation.

The respondents' choices are analyzed by using a well-tested random utility theory (RUT) introduced by Thurston ${ }^{8}$ in 1927 . According to RUT, utility is a latent construct that is not fully observational to the examiner, and consists of two components - a systematic (explicable) and a random one (inexplicable). The systematic component consists of attributes which explain the differences between the alternatives and covariates that explain the differences in the choice of the individuals, while the random component includes all the unidentified factors that influence the choice. Furthermore, as individuals are imperfect units of measure, the random component may also include factors that influence the variability associated with the individual, and not the option of choice per se. Finally, RUT estimates the maximum likelihood of possible choice with regard to the attributes of the alternatives, i.e. the model estimates the coefficients that maximize the probability of the actual respondents' choice, with the assumption that the individual seeks to maximize his level of utility.

\subsection{The construction of discrete choice experiment in healthcare}

The attributes, within a discrete choice method, are the variables that have two or more fixed levels, whereas the identification and the selection of attributes and their levels is the initial step in the process of experimental design, which has the biggest impact on the obtained experiment results and their validity (Kløjgaard et al., 2012). In determining the attributes it is important to avoid a conceptual overlap between attributes, in statistics known as the correlation, because that would disable the exact estimation of the main effect ${ }^{9}$ of each attribute on the dependent variable, while the range of the selected levels of attributes should include realistic situations, in this way increasing the accuracy of the estimated parameters (Hall et al., 2004). Furthermore, it is necessary to ensure a balance of the experimental design, i.e. to ensure the occurrence of different levels of attributes about the same

8 The theory and methods of discrete choice analysis were further on developed by McFadden (1973) for which he received the Nobel Prize in Economics in 2000.

9 The main effect refers to the direct independent impact of change in the level of attribute on the variable of the choice, while the indirect effect refers to the impact of the simultaneous variation of two or more attributes. 
number of times, which minimizes the variance in the estimated parameters (Mangham et al., 2009). The third feature that characterizes an effective design is the minimal overlap, meaning that the researcher should minimize the likelihood of repeating the same level of the attribute because the value of an attribute can be determined only by a comparison with other attributes.

Most recently, improved methods of experimental design such as the orthogonal array ${ }^{10}$ and D-efficient design ${ }^{11}$ are used and new software solutions for creation of choice sets are developing. However, in spite of the progress in the design, a lot of choice experiments are based on a statistically inefficient design (Louviere \& Lancsar, 2009). Besides the statistical properties of experimental design that should be satisfied (identification and precision), Louviere, Hansher and Swait (2000) point to two non-statistical properties that affect the suitability of the design, such as cognitive complexity and market reality. DCE tends to simulate market choices and establish consistency in the respondent's choice. Therefore, it is necessary to correctly identify relevant attributes in the decision-making process and to determine the significant attribute levels, for which it is necessary to first conduct a qualitative analysis that will include the opinions and the experiences of all relevant respondents. Although qualitative analysis is used in the majority of empirical studies for the identification of attributes and their levels and pilot testing of the entire questionnaire, qualitative process is recorded only in one third of the conducted researches (cf. de Bekker-Grob et al., 2012), thus calling for better reporting of the qualitative process.

The next key aspect of the application of DCE methodology is certainly the choice of the econometric model for the analysis of individuals' choices. The analysis typically implies the use of a logistic regression model with a categorical dependent variable such as logit, probit or multinomial logit (MNL), whereas the starting point in choosing the most appropriate model is the error distribution of the model. Earlier studies in healthcare (Ryan \& Gerard, 2003) were mostly investigating binary choices or the so-called forced choices using probit and logit models in the analysis of the obtained data. However, with the recognition of the need for and the importance of multiple selections (e.g. the possibility of opt-out) the application of MNL (de BekkerGrob et al., 2012) was imposed. As MNL is based on the assumptions that are very restrictive with regard to human behavior, and can limit the reality when considering the various options of healthcare policy, there is an increasing emphasis on the use of models of greater flexibility, such as nested logit, latent class logit and mixed logit.

10 Fractional factorial design that is both orthogonal and uniform is known as the orthogonal array. The orthogonal array exists only in certain combinations of attributes and their levels, while for the other combinations a compromise between the degree of orthogonality and balance has to be found (Mangham et al., 2009). The researcher should choose the most efficient design, for what is proposed D-efficient design (Burgess \& Street, 2005).

11 A review of the literature in the period 1990-2000 has not found any work that used D-efficient design, while in the period 2001-2008 12 DCEs were recorded in which D-efficient design was used, using SAS statistical program (de Bekker-Grob et al., 2012). 
Although the application of DCE in healthcare is marked by the improvement in the statistically efficient design and the development of econometric models, progress is lacking in the field of external validity with respect to hypothetical bias in the data. Precisely because the respondents' hypothetical choices are tested, DCE is subject to criticism in the part that it does not reflect the actual choices of individuals and therefore is not suitable for evaluating and predicting the effects of changes in health policies. In previous studies the internal validity of the model was mostly examined (i.e. DCE axioms about the completeness (the individuals form and express the complete set of their preferences), rationality (individuals prefer more in respect to less good) and continuity (individuals substitute all features by each other) were tested) which confirmed (Ryan \& Gerard, 2003) the existence of the completeness of preferences and rationality of the respondents but suggested irregularity of the axiom of continuity.

\subsection{Application in healthcare}

The main reason for the introduction and use of DCE in healthcare was to overcomeQALY framework (Louviere \& Lancsar, 2009), and to enable evaluation of non-health outcomes (Ryan \& Gerard, 2003). As the initial introduction of DCE in healthcare aimed at stressing the importance of non-health outcomes and process characteristics (Ryan \& Gerard, 2003), the same method was used for measuring the compromises which individuals are willing to make in relation to the process characteristics and the resulting consequences on health, and some studies (Ryan, 1999) showed that respondents were willing to change a substantial part of the potential improvement of health state for the better care during the process of medical intervention. In many DCE studies, there were investigated the relative importance of experience attributes, the compromises between different attributes, the willingness to pay for the marginal change of the attribute as well as the overall monetary value of different configurations of services (cf. de Bekker-Grob et al., 2012).

Until the year 2000, DCE was not particularly widespread in health economics ${ }^{12}$, partly because of limited interest of the pharmaceutical industry and government in the use of economic evaluation based on preferences. However, the interest in this method has significantly increased over the last decade, especially in the UK, Australia, the U.S., and Denmark and the Scandinavian countries (Kjær, 2005), which has increased the use and dissemination of DCE as well as the comprehension of its wider use. Today, the DCE is also used for evaluation of health outcomes (cf. de Bekker-Grob et al., 2012); prediction of the acceptance of new policies or healthcare programs (Hall et al. 2002); exploration of the compromise between health outcomes

12 In the period 1990-2000 34 studies (3 a year) in Great Britain were identified (Ryan \& Gerard, 2003), and in the period 2001-2004 25 (7 a year) new studies were conducted and the following 80 until July 2007 (27 a year) (de Bekker-Grob et al., 2012). 
and patients' experience factors (Gyrd-Hansen, 2004; Lanscar et at., 2007); exploration of preferences of certain groups of respondents ${ }^{13}$.

DCE have mostly been applied in health economic research in high-income settings with UK being the leading contributor to the literature followed by US, Australia, and Canada (de Bakker-Grob et al., 2012) and there are only few DCE health economic research conducted in low- and middle-income countries with a growing interest in the use of DCE in African countries e.g. Ghana, Ethiopia, Tanzania, Zambia (cf. Mangham et al., 2009). Although the usefulness of DCE is not jet recognized in the countries of Eastern Europe and former Yugoslavian countries it can be expected that the usefulness of the multi-criteria approach to health priority setting and advantages of DCE will certainly be recognized in the hear future.

\section{Conclusion}

Recent years have been marked by the economic crisis, but also healthcare crisis caused by demographic and health reasons, such as the aging of the population and the increased burden of chronic disease in developed countries. This creates a lot of pressure on budget spending and threatens the sustainability of national healthcare systems. Thus, the need and the importance of prevention and public preventive interventions arise, whereby it is important to ensure a certain level of effectiveness of preventive interventions in order to achieve its cost-effectiveness.

As healthcare is a non-market commodity, its value (utility) can be determined by using RP or SP methods within the economic evaluations that have shown to be a good decision-making framework in situations of budget constraint. But along with evaluation of preventive interventions it is also important to achieve a certain level of its effectiveness (e.g. adequate uptake). Therefore, when planning public health services or interventions it is important to take into consideration the factors that affect the demand because the success (effectiveness) of the implementation of public health interventions will depend on it. This is why patients' preferences and the factors that influence their decision-making should be included in the process of design, customization and implementation of those interventions.

In addition to being very useful for the economic evaluation of health interventions (assessment of social value), DCE is also suitable for their improvement because it enables the determination of the way in which preferences affect individual decision-making. DCE method seeks to identify the relationships in which goods (attributes) are substituted by each other,

13 For example, Bishop et al. (2004) compared the preferences of healthcare professionals and patients in relation to the screening test; Hall et al. (2006) compared the preferences of the general population and high-risk subgroups in relation to genetic screening; Ubach and others (2003) compared the preferences of pharmacists and general practitioners in relation to the electronic prescribing system; Bech (2003) compared the preferences of politicians and hospital management in relation to the compensation system. 
at the same time maintaining the same level of utility, i.e. the marginal rate of substitution and its impact on the respondents' choice, which is of great importance in sectors with strong budget constraints. This substitutability feature is at the heart of microeconomic concept of value as trade-offs that consumers are making by choosing smaller quantities of one good for larger quantities of another good, revealing the essence of value which they assign to a good, enabling a broad application of the method for the purposes of planning public health policies.

Nikolina Dukic is teaching assistant for the courses of Microeconomics and Advanced Microeconomics at the University of Rijeka, Faculty of Economics. After she graduated from the Faculty of Economics in Rijeka in 2006 she worked in a bank in the department of treasury. From 2009 she is teaching assistant at Faculty of Economics in Rijeka. Currently she is working on her habilitation in the field of health economics in cooperation with the Institute of Public Health in Rijeka. 
Nikolina Dukić

\section{References}

- Bateman, I. et al. (2002). Economic Valuation with Stated Preference Techniques: a Manual. Cheltenham: Edward Elgar Publishing Inc.

- Bech, M. (2003). Politicians' and hospital managers' trade-offs in the choice of reimbursement scheme: a discrete choice experiment. Health policy 66(3), 261-275.

- Becker, G. S. (1965). A theory of allocation of time. The Economic Journal 75, 493-517.

- de Bekker-Grob, E. W., Ryan M., \& Gerard, K. (2012). Discrete choice experiments in health economics: a review of the literature. Health Economics 21(2), 145-172.

- Belkar, R., \& Fiebig, D. G. (2004). Use of discrete choice experiments in health economics: An update of the literature. Working paper. School of Economics University of New South Wales.

- Bishop, A. J., Marteau, T. M., Amstrong, D., Chitty, L. S., Longworth, L., Buxton, M. J., \& Berlin, C. (2004). Women and health care professionals' preferences for Down's Syndrome screening tests: a conjoint analysis study. An international Journal for Obstetrics and Gynecology 111, 775-779.

- Burgess, L., \& Street, D. J. (2005). Optimal designs for choice experiments with asymmetric attributes. Journal of Statistical Planning and Inference 134, 288-301.

- Busse, R., Blümel, M., Scheller-Kreinsen, D., \& Zentner, A. (2010). Tackling chronic disease in Europe: Strategies, interventions and challenges. Observatory Studies Series No 20. Copenhagen: European Observatory on Health Systems and Policies.

- Clarke, J. L. (2010). Preventive Medicine: A Ready Solution for a Health Care System in Crisis. Population Health Management 13(2), S3-11.

- Green, C. (2009). Investigating public preferences on 'severity of health' as a relevant condition for setting healthcare priorities. Social Science \& Medicine 68, 2247-2255.

- Grossman, M. (1999). The Human Capital Model of the Demand for Health. Working Paper. New York: National Bureau of Economic Research.

- Gyrd-Hansen, D. (2004). Investigating the social value of health changes. Journal of Health Economics 23, 1101-1116.

- Hall, J. P., Kenny, P., King M., Louviere, J., Viney, R., \& Yeoh, A. (2002). Using Stated Preference Discrete Choice Modeling to Evaluate the Introduction of Varicella Vaccination. Health Economics 11(5), 457-65.

- Hall, J. P., Viney, R., Haas, M., \& Louviere, J. (2004). Using stated preference discrete choice modeling to evaluate health care programs. Journal of Business Research 57(9), 1026-1032.

- Hall, J. P., Fiebig, D. G., King, M., Hossain, I., \& Louviere, J. J. (2006). What influences participation in genetic carrier testing?: Results from a discrete choice experiment. Journal of Health Economics 25, 520-537.

- Keneth, D. S. (1994). The demand for preventive medical care. Applied Economics 26, 313-325.

- Kenneth E. T., \& David H. H. (2006). The Rise In Spending Among Medicare Beneficiaries: The Role Of Chronic Disease Prevalence And Changes In Treatment Intensity. Health Affairs 25(5), w378-w388.

- Kenkel, D. S. (1994). The demand for preventive medical care. Applied Economics 26, 313-325. 
- Kenkel, D. S. (2000). Prevention. In: Culyer, A. J. \& Newhouse, J. P. (Eds.), Handbook of Health Economics. Vol. 1. Amsterdam: Elsevier Science.

- Kjær, T. (2005). A review of the discrete choice experiment - with emphasis on its application in health care. Odense: University of Southern Denmark.

- Kløjgaard, M. E., Bech, M., \& Søgaard, R. (2012). Designing a Stated Choice Experiment: The Value of a Qualitative Process. Journal of Choice Modeling 5(2), 1-18.

- Lancaster, K. (1966). A new approach to consumer theory. Journal of Political Economy 74, 132-157.

- Lanscar, E., Louviere, J., \& Flynn, T. (2007). Several methods to investigate relative attribute impact in stated preference experiments. Social science \& Medicine 64, 1738-1753.

- Lancsar, E., Wildman, J., Donaldson, C., Ryane, M., \& Baker, R. (2011). Deriving distributional weights for QALYs through discrete choice experiments. Journal of Health Economics 30, 466-478.

- Louviere, J. J. Hensher, D. A., \& Swait, J. D. (2000). Stated Choice Methods: Analysis and Applications. Cambridge: Cambridge University Press.

- Louviere, J. J., \& Lancsar, E. (2009). Choice experiments in health: the good, the bad, the ugly and toward a brighter future. Health Economics, Policy and Law 4, 527-546.

- Mangham, L. J., Hanson, K. \& McPake, B. (2009). How to do (or not to do)... Designing a discrete choice experiment for application in a low-income country. Health Policy and Planning 24, 151-158.

- Mathers, C. D., \& Loncar, D. (2006). Updated projections of global mortality and burden of disease, 2002-2030: data sources, methods and results. Evidence and Information for Policy Working Paper. Geneva: World Health Organization. Retrieved 26. 9. 2012, from: http://www.who.int/healthinfo/ statistics/bodprojections2030/en/index.html

- McFadden, D. (1973). Conditional Logit Analysis of Qualitative Choice Behavior. In: Zarembka, P. (Ed.), Frontiers in Economics. New York: Academic Press.

- McKee M., \& Nolte, E. (2004). Responding to the challenge of chronic diseases: ideas from Europe. Clinical Medicine 4, 336-342.

- Meier, V. (2000). On the demand for preventive care. OR-Spectrum 22(3), 381-402.

- Merino-Castelló, A. (2003). Eliciting Consumers Preferences Using Stated Preference Discrete Choice Models: Contingent Ranking versus Choice Experiment. UPF Economics and Business Working Paper No. 705. Retrieved 2. 9. 2012, from: http://ssrn.com/abstract $=562982$

- Mirelman, A. (2012). Decision-Making Criteria among National Policymakers in Five Countries: A Discrete Choice Experiment Eliciting Relative Preferences for Equity and Efficiency. Value in Health 15, 534-539.

- Nolte, E., Knai, C., \& McKee, M. (2008). Managing chronic conditions: Experience in eight countries. Observatory Studies Series No 15. Copenhagen: European Observatory on Health Systems and Policies.

- OECD. (2011). Health at a Glance 2011: OECD Indicators. OECD Publishing. Retrieved 25. 9. 2012, from: http://dx.doi.org/10.1787/health_glance-2011-en

- Pelletier, K. R., Herman, P. M., Metz, R. D., \& Nelson, C. F. (2009). Health and Medical Economics: Applications to Integrative Medicine. Institute of Medicine. The Journal of Science and Healing 6(2), 86-99. 
- Phelps, C. E. (1978). Illness prevention and medical insurance. Journal of Human Resources 13, 183-207.

- Poulsen, R. J., Gyrd-Hansen D., \& Poulsen P. B. (2008). The economy. In: Kristensen, F. B. \& Sigmund, H. (Eds.), Health Technology Assessment Handbook. Copenhagen: National Board of Health.

- Russel, L. (1986). Is Prevention Better than Cure? Washington DC: The Brooking Institution.

- Ryan, M. (1999). Using conjoint analysis to take account of patient preferences and go beyond health outcomes: an application to in vitro fertilization. Social Science \& Medicine 48, 535-546.

- Ryan, M. \& Gerard, K. (2003). Using discrete choice experiments to value health care programs: current practice and future research reflections. Applied Health Economics and Health Policy 2(1), 55-64.

- Ryan, M., Netten, A.,Skåtun, D., \& Smith, P. (2006). Using discrete choice experiments to estimate a preference-based measure of outcome: An application to social care for older people. Journal of Health Economics 25, 927-944.

- Sassi, F., \& Hurst, J. (2008). The Prevention of Lifestyle-Related Chronic Diseases: an Economic Framework. OECD Health Working Paper No. 32. Paris: Directorate For Employment, Labour And Social Affairs Health Committee.

- Sculpher, M. J., \& Drummond, M. F. (2006). Analysis Sans Frontiers, Can we Ever Make Economic Evaluation Generalisable: Across Jurisdictions. Pharmacoeconomics 24(11), 1087-1099.

- Suhrcke, M., Nugent, R. A., Stuckler, D., \& Rocco, L. (2006). Chronic Disease: An Economic Perspective (Annex). London: The Oxford Health Alliance. Retrieved 26. 9. 2012, from: www.oxha.org/initiatives/economics

- Ubach, C., Scott, A., French, F., Awramenko, M., \& Needham, G. (2003). What do hospital consultants value about their jobs? A discrete choice experiment. British Medical Journal 326(7404), 1432-1437.

- Wei-Hua, T., Chin-Shyan, C., \& Tsai-Ching, L. (2010). The demand for preventive care services and its relationship with inpatient services. Health Policy 94(2), 164-174.

- Zweifel, P., Breyer, F., \& Kifmann, M. (2009). Health Economics, Second Edition. Heidelberg: Springer. 
POVZETEK

\section{UPORABNOST METODE DISKRETNE IZBIRE PRI ZAGOTAVLJANJU UČINKOVITE ZDRAVSTVENE OSKRBE}

Ključne besede: javno zdravstvo, izdatki za javno zdravstvo, preventiva, ocena preferenc, metoda diskretne izbire

Slabo zdravje in kronična bolezen lahko vplivata na ekonomijo preko porabe in prihrankov (investicije), kot tudi na stopnjo izobrazbe. Empirična raziskava na mikroravni je pokazala, da kronične bolezni znižujejo plače, dobiček, sodelovanje delovne sile in produktivnost, medtem ko hkrati vplivajo na zgodnje upokojevanje, invalidnino in visoko stopnjo fluktuacije zaposlenih. Glede na to, da se breme kroničnih bolezni v času krize povečuje, vedno bolj pomembni postajajo preventivni ukrepi, saj vplivajo na vzdrževanje in izboljšanje zdravja prebivalstva in tako zmanjšujejo vladne stroške za bolniški dopust in invalidnino. Učinkovita raba preventive pomaga tudi zmanjšati potrebe po zdravljenju in s tem povezane visoke stroške zdravniške oskrbe, kar je dandanes zelo pomembno.

Če vlada želi investirati svoja omejena sredstva v programe javnega zdravstva, ki bodo najbolj zanimivi za skupnost, je potrebno, da poleg stroškovne plati oceni tudi koristno plat, kar vključuje tudi vprašanje definicije in merjenja koristi. Ekonomsko vrednotenje na področju zdravstva, ki teoretično temelji na ekonomiji blaginje, je pokazalo, da je dober okvir za odločanje v času proračunskih omejitev. Za njegovo uporabo vlada povečano zanimanje, saj izvajanje ekonomskega vrednotenja igra pomembno vlogo pri postavljanju prioritet pri stroških zdravstvenega varstva. Velik del raziskav na področju zdravstvene ekonomike temelji na nedenarni oceni preferenc in oceni koristi, znotraj opravljenega ekonomskega vrednotenja, ki skoraj v celoti temeljijo na zdravstvenih rezultatih, kot je razvidno iz široko razširjene uporabe mere »leta zdravstveno kakovostnega življenja« (QALY) v analizi stroškovne uporabnosti (CUA). Vendar pa je sledila kritika uporabe QALY, ki je navajala, da osredotočenost na maksimizacijo izključno enega cilja (zdravje) zanemarja številne druge pomembne vidike pri razvrščanju v javnem zdravstvu, kot so potrebe, učinkovitost in enakost. Poleg teh se na uporabo QALY nanaša še ugovor glede zanemarjanja socialnih preferenc za pravično razdelitev zdravstva.

$\checkmark$ skladu s teorijo blaginje so posamezniki najboljši sodniki svoje blaginje in če, na podlagi domneve, da najvišji znesek, ki so ga posamezniki pripravljeni plačati (žrtvovati) za posamezno dobrino ali storitev, nakazuje njihovo raven koristnosti, je denarna vrednost koristi določena s posameznikovo pripravljenostjo za plačilo (WTP). Zato se lahko stopnjo blaginje določi z opazovanjem dejanskih izbir posameznikov na trgu (RP) ali s preizkušanjem 
hipotetične izbire posameznikov (SP), ki ne zahteva, da so koristi izražene samo glede na zdravje in z zdravjem povezano kakovostjo življenja (QALY). Ob predpostavki racionalnega obnašanja posameznikov bi morala biti odzivnost na preventivne ukrepe (razkrite preference) visoka, medtem ko bi nizka odzivnost ciljne populacije nakazovala na nizko socialno vrednost preventivnih zdravstvenih ukrepov. Postavlja se vprašanje, ali razkrite preference (odzivnost) v primeru (ne)odzivanja na preventivne ukrepe, ponujajo vpogled v vrednost (korist) preventivnih ukrepov. Dobro je znano, da čeprav lahko posamezniki določene ukrepe obravnavajo kot koristne, ni nujno, da bodo ravnali v skladu s tem, kar lahko pripelje do popačene vrednosti na osnovi razkritih preferenc. Kljub temu so ekonomisti običajno (upravičeno) skeptični, ko pride do zanašanja na izrečene preference. Vendar pa v določenih situacijah ni druge izbire, kot zanesti se na pričevanje potrošnika/pacienta, ali pa ne ukrepati, kot v primeru zdravstvenega varstva, kjer se je zanimanje za uporabo tehnik SP (kot so kontingenčno vrednotenje in metoda diskretne izbire) dramatično povečalo od sredine devetdesetih let dalje.

V zadnjem času se $v$ številnih raziskavah v zdravstveni ekonomiki uporablja metoda diskretne izbire (DCE), kar lahko pripišemo številnim prednostim metodologije. V DCE se namreč anketiranci odločajo skladno s tem, kakor bi se dejansko odločili na pravem trgu, in je bolj primerna v situacijah, ko je nujno oceniti več atributov hkrati, medtem ko bi pri kontingenčnem vrednotenju (CV) potrebovali izdelavo več scenarijev. Še ena prednost DCE v primerjavi s CV je v zmanjšani multikolinearnosti med atributi in izognitvi nekonsistentnosti v odgovorih anketirancev, ki so značilni za metodo CV. Poleg tega DCE poskuša identificirati odnose, v katerih se atributi zamenjajo drug z drugim in hkrati ohranijo enako raven koristnosti, tj. mejno stopnjo substitucije (MRS) in njen vpliv na izbire anketirancev, kar omogoča široko uporabo metode. V tem pogledu je največja prednost in edinstvenost DCE v tem, da se lahko uporabi tako pri analizi stroškov in koristi (ocenjevanje denarne vrednosti WTP) kot pri analizi stroškovne uporabnosti (ocenjevanje uteži uporabnosti znotraj QALY).

Teoretični okvir DCE vsebuje elemente tradicionalne mikroekonomske teorije vedenja potrošnikov, kot so formalna definicija racionalne izbire. Vendar pa se temeljni premik od tradicionalne teorije potrošništva odraža v okolju, tako da potrošnik pridobi korist od značilnosti (atributov), ki so povezane z dobrino, in ne od dobrine same po sebi. Atributi, znotraj metode diskretne izbire, so spremenljivke, ki imajo dve ali več fiksnih stopenj, medtem ko sta določitev in izbira atributov in njihovih stopenj začetni korak v procesu načrtovanja poizkusa, kjer je končni rezultat vprašalnik z različnimi scenariji, ki vsebujejo alternative, opisane z ustreznimi ravnmi atributov. Z zagotavljanjem razlik v scenarijih je mogoče določiti odnose, v katerih se atributi zamenjajo drug z drugim, in preučiti, v kolikšni meri vsak od atributov vpliva na izbire posameznikov. Ker se DCE nagiba k simulaciji odločitev na trgu in vzpostavitvi doslednosti anketirančevih odločitev, je treba pravilno opredeliti pomembne atribute $v$ procesu odločanja in določiti stopnje pomembnih atributov, 
za kar je treba najprej opraviti kvalitativno analizo, ki bo vključevala mnenja in izkušnje vseh pomembnih anketirancev.

Z uporabo dobro preizkušene teorije slučajne koristnosti (RUT) analiziramo izbiro danih možnosti, ki so jo opravili anketiranci. Teorija ocenjuje največjo verjetnost mogoče izbire z obzirom na atribute možnosti, tj. model oceni koeficiente, ki maksimizirajo verjetnost dejanske izbire anketirancev, s predpostavko, da posameznik želi maksimizirati svojo stopnjo koristnosti. Po RUT je koristnost latentni konstrukt, ki ga opazovalec ne opazuje v celoti in je sestavljen iz dveh delov - sistematičnega (razložljivega) in naključnega (nerazložljivega). Analiza običajno nakazuje uporabo logističnega regresijskega modela s kategorično odvisno spremenljivko, kot so model logit, model probit ali multimodalni logit (MNL), medtem ko je izhodiščna točka pri izbiri najprimernejšega modela napačna porazdelitev modela. Ker MNL temelji na predpostavkah, ki so zelo omejevalne glede človeškega vedenja in lahko omejijo realnost, ko upoštevajo različne možnosti zdravstvene politike, je vedno večji poudarek na uporabi modelov, ki so bolj prilagodljivi, kot so hierarhični logit, logit latentne spremenljivke in mešani logit.

Do leta 2000 DCE ni bila posebej razširjena v zdravstveni ekonomiki, deloma zaradi omejenega interesa farmacevtske industrije in vlade za uporabo ekonomske ocene na podlagi preferenc. Vendar pa se je zanimanje za to metodo v zadnjem desetletju znatno povečalo, še posebej v Veliki Britaniji, Avstraliji, ZDA, na Danskem in v skandinavskih državah, kar je povečalo uporabo in širjenje DCE, kot tudi razumevanje njene širše uporabe. Začetna uvedba DCE v zdravstvu je bila namenjena poudarjanju pomena rezultatov, ki niso povezani z zdravjem, in lastnosti procesa. Danes pa se DCE uporablja za ocenjevanje zdravstvenih izidov; napovedovanje sprejema novih politik ali zdravstvenih programov; raziskovanje kompromisov med zdravstvenimi izidi in dejavniki izkustva pacientov; raziskovanje preferenc posameznih skupin anketirancev.

Poleg tega, daje zelo koristna za ekonomskovrednotenje zdravstvenih ukrepov in oceno njihovega družbenega pomena, je metoda DCE primerna tudi za izboljšanje ukrepov, saj omogoča opredelitev načina, pri katerem preference vplivajo na posameznikovo odločitev. Metoda DCE poskuša določiti razmerje, v katerem se dobrine zamenjajo z drugimi, hkrati pa ohranjajo isto stopnjo koristnosti, tj. mejno stopnjo substitucije, kar je velikega pomena v sektorjih s strogimi proračunskimi omejitvami. Ta funkcija zamenljivosti je bistveni del mikroekonomskega koncepta vrednosti kot odločitve potrošnikov, da izberejo manjše količine ene dobrine namesto večje količine druge dobrine in s tem razkrivajo vrednost, ki jo dodelijo tej dobrini. Prav v tem je pomen uporabe metode DCE za načrtovanje politike javnega zdravstva. 